\title{
TRANSFER OF ESCHERICHIA COLI ANTIBODIES FROM SOW TO PIGLET
}

\author{
B. J. Shreeve AND J. R. Thomlinson \\ Department of Veterinary Pathology, University of Liverpool
}

EARLIER experiments (Shreeve and Thomlinson, 1970a, 1971a) showed that piglets may be hypersensitive to certain serotypes of Escherichia coli at birth, and that pregnant sows immunised with either hen egg albumin or $E$. coli extracts conferred hypersensitivity on their young whether or not they had received colostrum. Sensitisation of the piglets may have resulted from transfer of maternal antibody across the placental barrier, or from transfer of antigen leading to active immunisation of the piglets.

The purpose of the following experiments was to determine whether antibodies could be detected in the serum of newborn colostrum-deprived piglets from immunised dams and to investigate the origin of these antibodies.

\section{MATERIALS AND METHODS}

Animals. Pregnant Large-White sows were obtained from the same source as those used in previous experiments (Shreeve and Thomlinson, 1970a). Piglets were separated from their dams before they received colostrum; blood samples were obtained from the anterior vena cava immediately after birth.

Active immunisation of sows. Five pregnant sows were immunised with $E$. coli serotype O138:K81(B) extract prepared by the method of Erskine, Sojka and Lloyd (1957). The immunisation procedure was similar to that employed in previous experiments (Shreeve and Thomlinson, 1971a) except that, in two of the sows, it was begun in the first third of pregnancy, about the 35th day. All five received an intravenous injection of $2 \mathrm{ml}$ of the same $E$. coli extract within $2 \mathrm{hr}$ before parturition; this caused mild symptoms of shock.

Two sows were immunised by the injection of a heat-killed formolised suspension of E. coli $\mathrm{O} 138: \mathrm{K} 81(\mathrm{~B})$ by the intravenous route. Cultures were prepared on nutrient agar in Roux flasks and incubated at $37^{\circ} \mathrm{C}$ for $48 \mathrm{hr}$. The organisms were suspended and washed three times in sterile isotonic saline and were then heated in a waterbath at $60^{\circ} \mathrm{C}$ for $1 \mathrm{hr}$. Formaldehyde was added to give a concentration of 0.2 per cent. Before use, the suspension was diluted in saline to an opacity equal to that of Brown's tube no. 1. Three courses of injections were given at intervals of 10 days; each consisted of four injections at $48 \mathrm{-hr}$ intervals and the dose was increased progressively from $2 \mathrm{ml}$ in the first course to $5 \mathrm{ml}$ in the last. The final injection was given 10 days before the expected date of parturition.

Passive immunisation of sows. Antiserum prepared from blood collected from sows that had been immunised with $E$. coli $\mathrm{O} 138: \mathrm{K} 81(\mathrm{~B})$ extract was stored at $-30^{\circ} \mathrm{C}$. The pooled antiserum had an " $O$ " agglutinin titre of 20,480 . Two sows were each given an intravenous injection of $150 \mathrm{ml}$ antiserum either 24 or $48 \mathrm{hr}$ before parturition. This injection caused mild signs of shock.

Immunoglobulin was prepared by adding ammonium sulphate to the antiserum to give a concentration of 40 per cent. The mixture was held at $4^{\circ} \mathrm{C}$ for $18 \mathrm{hr}$ and centrifuged at 4500 r.p.m. for $45 \mathrm{~min}$. The precipitate was dissolved in a minimal amount of distilled water and dialysed at $4^{\circ} \mathrm{C}$ overnight against a large volume of distilled water. The dialysate was 
freeze-dried, stored at $4^{\circ} \mathrm{C}$ and, when required, reconstituted in distilled water so that $250 \mathrm{ml}$ of reconstituted immunoglobulin solution was equivalent to $2000 \mathrm{ml}$ of the original serum. One sow was given an intravenous injection of $150 \mathrm{ml}$ of immunoglobulin $48 \mathrm{hr}$ before parturition. Mild signs of shock developed.

Bactericidal tests. Cultures of $E$. coli $0138: \mathrm{K} 81(\mathrm{~B})$ were made on nutrient agar and incubated at $37^{\circ} \mathrm{C}$ for $18 \mathrm{hr}$. The growth on each plate was tested for agglutination with homologous "OK" antiserum and suspended in $10 \mathrm{ml}$ of nutrient broth. This suspension was diluted with nutrient broth until it gave a reading of 0.12 on a spectrophotometer at a wavelength of $695 \mathrm{~nm}$. For use in the test, the standardised suspension was diluted 10-6 in sterile isotonic saline. Pooled lyophilised guinea-pig serum was used as a source of complement and the tests were performed in complement excess (Muschel and Treffers, 1956). In the tests, equal volumes of bacterial suspension and guinea-pig serum were incubated at $37^{\circ} \mathrm{C}$ for $2 \mathrm{hr}$ with two volumes of the serum under test. From each test, four nutrient-agar plates were each inoculated by spreading $0.02 \mathrm{ml}$ of the fluid evenly over the surface. Control tubes containing 1 volume of saline in place of the guinea-pig serum, and 3 volumes of saline in place of the guinea-pig serum and test serum, were treated similarly. The percentage bactericidal effect was estimated from the average bacterial count in each test. Control tubes yielded counts of about 200 colonies.

Passive cutaneous anaphylactic (PCA) tests. The method used for PCA tests was similar to that of Buxton and Thomlinson (1961), except that colostrum-deprived piglets were used as the test animals because fixation may be more efficient in the homologous species (Vaz and Ovary, 1968). Twelve samples of serum were tested in each piglet by injecting them intradermally in $0.1 \mathrm{ml}$ amounts, six on each side of the midline of the abdomen. After $3 \mathrm{hr}$, each piglet was given an intravenous injection of $3 \mathrm{ml} E$. coli O138:K81(B) extract (Erskine et al.) diluted 1 in 15 and containing 0.5 per cent. pontamine sky-blue 6BX. The diameters of skin reactions were measured $90 \mathrm{~min}$. after the intravenous injection. Control piglets were given injections of $0 \cdot 1-\mathrm{ml}$ doses of the sera under test, but were challenged with $3 \mathrm{ml}$ of 0.5 per cent. pontamine sky-blue solution in sterile isotonic saline.

Haemagglutination and antiglobulin haemagglutination tests. These tests were performed as described by Buxton and Thomlinson. Tests on piglet serum were repeated after the serum had been concentrated eight-fold by absorption with polyethylene glycol across a collodion membrane.

\section{RESULTS}

Bactericidal tests (table I). Bactericidal activity was present in serum samples from 11 (47.8 per cent.) of the 23 colostrum-deprived piglets from the normal sows compared with 12 ( 71.4 per cent.) of the 17 piglets from the sows that were actively immunised in the final third of pregnancy. The serum of a piglet from one of the sows actively immunised from the first third of pregnancy showed bactericidal activity, although two piglets from a similarly immunised sow with a higher haemagglutinin titre gave negative results (table I).

In the case of passively immunised sows, sera from four out of five piglets showed bactericidal activity when antiserum had been administered $24 \mathrm{hr}$ before parturition; when antiserum or immunoglobulin had been injected $48 \mathrm{hr}$ before parturition, sera from four out of nine and three out of six piglets, respectively, gave positive results.

Passive cutaneous anaphylactic tests. Sera from ten of the piglets from normal sows were subjected to the PCA test and all gave negative results although five of them had shown bactericidal activity. Except in the case of one piglet from a sow that had been immunised early in pregnancy, antibodies were not detected by PCA tests in sera from piglets from the actively immunised 
TABLE I

Bactericidal and $P C A$ activity in sera of piglets from a normal sow and from sows actively and passively immunised with an extract of E. coli serotype $0138: K 81(B)$

\begin{tabular}{|c|c|c|c|c|c|c|}
\hline \multirow{2}{*}{ Treatment of sow } & \multirow{2}{*}{$\begin{array}{l}\text { Number } \\
\text { of sows }\end{array}$} & \multirow{2}{*}{$\underset{\text { titre* }}{\mathrm{HA}}$} & \multicolumn{2}{|c|}{$\begin{array}{l}\text { In bactericidal tests, } \\
\text { number of piglets }\end{array}$} & \multicolumn{2}{|c|}{$\begin{array}{l}\text { In PCA } \dagger \text { tests, } \\
\text { number of piglets }\end{array}$} \\
\hline & & & tested & $\begin{array}{l}\text { whose serum } \\
\text { was positive }\end{array}$ & tested & $\begin{array}{l}\text { whose serum } \\
\text { was positive }\end{array}$ \\
\hline Normal & 4 & $10-20$ & 23 & 11 & 10 & 0 \\
\hline $\begin{array}{l}\text { Actively immunised in } \\
\text { first third of pregnancy }\end{array}$ & 2 & $\begin{array}{c}5120 \\
163,840\end{array}$ & $\begin{array}{l}1 \\
2\end{array}$ & $\begin{array}{l}1 \\
0\end{array}$ & $\begin{array}{l}1 \\
2\end{array}$ & $\begin{array}{l}1 \\
0\end{array}$ \\
\hline $\begin{array}{l}\text { Actively immunised in } \\
\text { last third of pregnancy }\end{array}$ & 3 & $\begin{array}{r}320 \\
1280 \\
1280\end{array}$ & $\begin{array}{l}5 \\
5 \\
7\end{array}$ & $\begin{array}{l}3 \\
4 \\
5\end{array}$ & $\begin{array}{l}2 \\
2 \\
2\end{array}$ & $\begin{array}{l}0 \\
0 \\
0\end{array}$ \\
\hline $\begin{array}{l}\text { Antiserum injected } 24 \mathrm{hr} \\
\text { before parturition }\end{array}$ & 1 & 80 & 5 & 4 & 5 & 5 \\
\hline $\begin{array}{l}\text { Antiserum injected } 48 \mathrm{hr} \\
\text { before parturition }\end{array}$ & 1 & 40 & 9 & 4 & 9 & 2 \\
\hline $\begin{array}{l}\text { Immuno-globulin injected } \\
48 \mathrm{hr} \text { before parturition }\end{array}$ & 1 & 80 & 6 & 3 & $\ldots$ & $\cdots$ \\
\hline
\end{tabular}

$*$ HA titre $=$ Haemagglutinin titre of sera from sows at parturition.

$\dagger$ PCA $=$ Passive cutaneous anaphylaxis.

TABLE II

Haemagglutination and antiglobulin-haemagglutination titres to E. coli serotype O138:K81(B) in newborn colostrum-deprived piglet sera from sows vaccinated with E. coli $O 138: K 81(B)$

\begin{tabular}{|c|c|c|c|c|c|}
\hline \multirow{2}{*}{ Sow no. } & \multicolumn{2}{|c|}{$\begin{array}{l}\text { Antibody titre of } \\
\text { sow serum in }\end{array}$} & \multirow{2}{*}{ Piglet no. } & \multicolumn{2}{|c|}{$\begin{array}{l}\text { Antibody titre of } \\
\text { piglet serum in }\end{array}$} \\
\hline & HA* test $^{*}$ & $A G \dagger$ test & & HA test & AG test \\
\hline 4971 & 1280 & 20480 & $\begin{array}{r}4971 / 1 \\
2 \\
3 \\
4 \\
5 \\
6\end{array}$ & $\begin{array}{l}10 \\
- \\
\overline{ \pm} \\
=\end{array}$ & $\begin{array}{r}80 \\
5 \\
- \\
10 \\
\pm \\
5\end{array}$ \\
\hline WA10 & 320 & 2560 & $\begin{array}{r}\text { WA10/1 } \\
2 \\
3 \\
4 \\
5 \\
6\end{array}$ & $\begin{array}{l}= \\
= \\
\overline{-} \\
=\end{array}$ & $\begin{array}{l}20 \\
= \\
= \\
-\end{array}$ \\
\hline
\end{tabular}


sows. Antibodies were demonstrated by the PCA test in all five piglets from the sow passively immunised $24 \mathrm{hr}$ before parturition. The skin reactions ranged from $4 \mathrm{~mm}$ to $8 \mathrm{~mm}$ diameter. Only two of the sera from the nine piglets of the sow that was passively immunised with serum $48 \mathrm{hr}$ before parturition showed PCA activity. Four of these samples had shown bactericidal activity. No samples were tested from piglets of the sow that had received immunoglobulin.

Haemagglutination and antiglobulin haemagglutination tests (table II). Antibodies were not detected by these tests on concentrated or unconcentrated sera from colostrum-deprived piglets of sows immunised with $E$. coli extract or of passively immunised sows. Antiglobulin haemagglutinating antibodies were demonstrated in concentrated sera from five of the colostrum-deprived piglets obtained from the two sows that had been immunised with $E$. coli heat-killed formolised suspension. Of these five piglets, four were derived from the sow with the higher antibody titre.

\section{DisCUSSION}

The results of these experiments show that antibody activity can be demonstrated in sera from newborn colostrum-deprived piglets. Whilst bactericidal activity was found in piglets from normal as well as from actively and passively immunised sows, passive cutaneous anaphylactic (PCA) activity occurred mainly in those from passively immunised sows. Haemagglutinating and antiglobulin-haemagglutinating activity were found only after heat-killed formolised whole culture had been used for immunisation of the sows.

It has been generally accepted that transfer of antibody from sow to piglet occurs only by way of the colostrum (McGirr, 1947; Brambell, 1958). Šterzl et al. (1960) estimated that the immunoglobulin content of pre-colostral piglet serum was $10-40 \mu \mathrm{g}$ per $\mathrm{ml}$, but were unable to demonstrate any antibody activity associated with this fraction. According to Sterzl et al. (1964), the bactericidal effect of pre-colostral piglet serum depends on the amount of complement present. The bactericidal tests recorded by us were performed in the presence of excess of complement and it is therefore improbable that the results were influenced by differences in complement content of the original samples. Bactericidal activity was found in several sera that showed no PCA activity, but the bactericidal test is the more sensitive means of detecting antibodies (Humphrey and White, 1964).

Antibodies detectable by the haemagglutination and antiglobulin-haemagglutination tests were found only in piglets from the two sows that had been immunised with killed whole bacteria, though the haemagglutinin titres of sows immunised with $E$. coli extract were comparable or higher. Moreover, correlation is lacking between the haemagglutinin titres of the sows and the frequency of bactericidal and PCA activity in their piglets. These observations suggest that antibody produced against $E$. coli extract may differ qualitatively from that produced against whole bacteria. There is evidence that haemagglutination and antiglobulin-haemagglutination tests detect mainly " $\mathrm{O}$ " macroglobulin 
(Shreeve and Thomlinson, 1971b), whereas bactericidal activity is associated, at least in part, with the IgG fraction (Porter and Hill, 1970).

Despite the relatively low serum-haemagglutinin titres of the passively immunised sows, bactericidal and PCA activity were detected in sera from most of the piglets from the sow that had received antiserum $24 \mathrm{hr}$ before parturition and from several piglets from the other two sows. According to Kim, Bradley and Watson (1966), the placental barrier of the pig does not normally allow transfer of antibody from sow to foetus. However, these workers found that antibody was transferred, presumably as a result of placental damage, after $E$. coli serotype $\mathrm{O} 8$ endotoxin had been injected into the sow. Similar placental damage resulting from the absorption of endotoxin may occur under natural conditions (Shreeve and Thomlinson, 1971b). In the present experiments, placental damage may have resulted from the mild shock that developed when the sows were given an injection of antiserum or immunoglobulin, and antibody may have been transferred at that time. In these circumstances, greater fixation of antibody would have occurred in the piglets from sows passively immunised $48 \mathrm{hr}$ before parturition; this would account for the higher proportion of negative results from sera of these piglets than from sera of piglets of the other passively immunised sow. Shreeve and Thomlinson (1970a) suggested that fixation of antibody may explain the failure of some workers to detect antibody in the serum of colostrum-deprived piglets.

In our investigations into naturally occurring $E$. coli disease of piglets (Shreeve and Thomlinson, 1970b), we found that the symptoms and lesions closely resembled those that occur in older pigs in association with anaphylaxis and oedema disease (Thomlinson and Buxton, 1962, 1963). It has been postulated (Shreeve and Thomlinson, 1970a, 1971a) that sensitisation may occur in newborn piglets either passively as a result of transference of maternal antibody across the placental barrier, or actively as a result of the transfer of antigen. The results recorded in this paper show that maternal antibodies to E. coli may be transferred to the piglet in utero. Thus passive sensitisation of the neonatal piglet may occur by means other than through the colostrum and may play a part in the pathogenesis of $E$. coli disease.

\section{SUMMARY}

Pregnant sows were immunised either actively by injecting a bacterial extract or a killed bacterial suspension prepared from Escherichia coli serotype O138:K81(B), or passively by injecting antiserum or immunoglobulins prepared against an extract of the same organism. Antibodies to this organism were detected in serum from the colostrum-deprived piglets of these sows by means of bactericidal, passive cutaneous anaphylaxis, haemagglutination, and antiglobulin-haemagglutination tests. The evidence suggests that piglets may be passively sensitised in utero as a result of the transfer of maternal antibody and that factors such as the character of the antibody and its fixation in the tissues may influence its detection in piglet serum. These results are discussed in relation to the role of hypersensitivity in the pathogenesis of $E$. coli disease in the newborn piglet. 
We wish to acknowledge the financial assistance of the Pig Industry Development Authority. Our thanks are due to Professor D. L. Hughes for his continued encouragement and helpful criticism.

\section{REFERENCES}

Brambell, F. W. R. 1958. Pre-natal transference of antibodies. Vet. Rec., 70, 1060.

Buxton, A., AND Thomlinson, J. R. 1961. The detection of tissue-sensitizing antibodies to Escherichia coli in oedema disease, haemorrhagic gastroenteritis and in normal pigs. Res. Vet. Sci., $2,73$.

Erskine, R. G., SoJKA, W. J., AND Lloyd, M. K. 1957. The experimental reproduction of a syndrome indistinguishable from oedema disease. Vet. Rec., 69, 301.

HumphreY, J. H., AND WhITE, K. G. 1964. Immunology for students of medicine, 2nd ed., Oxford, p. 201.

Kim, Y. B., Bradley, S. G., AND Watson, D. W. 1966. Ontogeny of the immune response. I. Development of immunoglobulins in germfree and conventional colostrum-deprived piglets. J. Immun., 97, 52.

McGrRR, J. L. 1947. Colostral transmission of antibody substances from mother to offspring. Vet. J., 103, 345.

Muschel, L. H., AND TREFFeRs, H. P. 1956. Quantitative studies of the bactericidal actions of serum and complement. I. A rapid photometric growth assay for bactericidal activity. J. Immun., 76, 1.

Porter, P., AND Hill, I. R. 1970. Serological changes in immunoglobulins IgG, IgA and IgM and Escherichia coli antibodies in the young pig. Immunology, 18, 565.

SHREEVE, B. J., AND ThOMLINSON, J. R. 1970a. Hypersensitivity in young piglets: its relation to the pathogenesis of Escherichia coli disease. J. Med. Microbiol., 3, 377.

Shreeve, B. J., AND Thomlinson, J. R. 1970b. Escherichia coli disease in the piglet. A pathological and bacteriological investigation. Br. Vet.J., 126, 444.

Shreeve, B. J., AND Thomlinson, J. R. 1971a. Hypersensitivity of young piglets to Escherichia coli endotoxin. J. Med. Microbiol., 4, 307.

Shreeve, B. J., AND Thomlnson, J. R. 1971b. Bacteriological and serological studies in preparturient sows. Br. Vet. J., 127, 57.

ŠTERZL, J., KostKA, J., RíHA, I., AND MANDEL, L. 1960. Attempts to determine the formation and character of gamma globulin and of natural and immune antibodies in young pigs reared without colostrum. Folia microbiol., Praha, 5, 29.

ŠTerzl, J., PeŠÁk, V., KostKA, J., and JíLEK, M. 1964. The relation between the bactericidal activity of complement and the character of the bacterial surfaces. Folia microbiol., Praha, 9, 284.

Thomlinson, J. R., AND Buxton, A. 1962. A comparison of experimental anaphylactic shock in guinea-pigs with naturally-occurring oedema disease and haemorrhagic gastro-enteritis in pigs. Res. Vet. Sci., 3, 186.

Thomlinson, J. R., AND Buxton, A. 1963. Anaphylaxis in pigs and its relationship to the pathogenesis of oedema disease and gastro-enteritis associated with Escherichia coli. Immunology, 6, 126.

VAZ, N. M., AND OvARY, Z. 1968. Passive anaphylaxis in mice with $\gamma$ G antibodies. I. PCA and RPCA reactions with homologous and heterologous antibodies. J. Immun., 100, 169. 